\title{
Rainwater harvesting for increasing livestock for- age on arid rangelands of Pakistan
}

\author{
SHEIKH SULEMAN, M. KARL WOOD, BASHIR HUSSAIN SHAH, AND LEIGH MURRAY
}

\begin{abstract}
Authors are former graduate student and professor of Watershed Management, Department of Animal and Range Sciences, New Mexico State University, Las Cruces 88003; director of Watershed Management, Pakistan Forest Institute, Peshawar, Pakistan; and associate professor of Experimental Statistics, Department of Experimental Statistics, New Mexico State University, Las Cruce 88003.
\end{abstract}

\begin{abstract}
This study determined forage production and cover of several plant species resulting from the use of water harvesting catchments with catchment: cultivated area ratios of $1: 1$ and 1.25:1 and contributing aprons with 7,10 , and $15 \%$ slope gradients. Plots with 1.25:1 ratios produced more forage and had more cover than plots with 1:1 and 0:1 ratios. Plots with 7, 10, and 15\% slope gradients had similar forage production and cover. Tuft planted plots produced more forage and cover than seeded plots. Ghorka (Elionurus hirsutus (Vahl) Munro), blue panicum (Panicum antidotale Retz.), and buffel (Cenchrus ciliaris L.) grasses produced similar forage and cover, which was higher than khev grass (Sporobolus helvolus (Trin.) Th. Dur. \& Schinz) production and cover.
\end{abstract}

Key Words: runoff, phytomass, foliar cover.

Many of the problems faced today by Pakistan, like many other developing nations, are related to water resources (e.g. land use, nomadic grazing, desertification, brush invasion, and food and industrial production). More than 87 million ha of Pakistan (70\% of the land area) are arid and semiarid rangelands and their use is limited to production of livestock forage.

Pakistan is divided into 4 provinces and each province is divided into districts. The North West Frontier Province contains the Dera Ismail Khan District, which covers 9,005 square kilometers with a human population of $804,000,82 \%$ of whom reside in rural areas. Internal migration within the province as well as immigration from other provinces and from outside the country, especially from Afghanistan, have been going on for at least decades, probably centuries and maybe millennia. Migration is most common during drought years. People along with their livestock migrate on foot to areas where they can get food and fodder for subsistence. Livestock grazing constitutes the biggest land use and abuse in the country. At present, the livestock population of Pakistan is about 93.5 million head, of which the majority rely on the arid and semiarid rangelands.

These seasonal migrations would not be as necessary if a dependable forage crop could be raised. The greatest barrier to a

Manuscript published with approval of the Director, New Mexico State University Agricultural Experiment Station.

Manuscript accepted 4 Feb. 1995. dependable forage crop is inadequate soil moisture. Labor is very inexpensive so topographic reshaping is feasible. The application of water harvesting systems to these lands may lead to improved forage production. Projects have been initiated in arid climates worldwide for several millennia to capture rainfall. Some examples were at Ur and other places in the Middle East as early as 8,500 B.P (Hardan 1975). Researchers have reconstructed water harvesting systems used for runoff farming in Israel's Negev Desert 4,000 years ago (Evenari et al. 1968). American Indians used similar systems 700 to 900 years ago in the southwestern United States (Myer 1975). Most of these projects used trial-anderror for design of catchment basin sizes and shapes, and sundry soil types. In some parts of the world, rainwater collected from the roofs of houses provides a household water supply. Although rainfall is infrequent and shallow in arid lands, it represents considerable amounts of water over large areas; $10 \mathrm{~mm}$ of rainfall equals 100 cubic meters per hectare. Harvesting this water can provide water for regions where other sources are distant or too costly, and well construction is impractical because of unfavorable geology. Harvested rainfall may be useful to increase soil moisture in selected areas for enhanced plant growth of species native to arid climates and growth of introduced species.

The primary objective of this study was to determine forage production and cover of various plant species resulting from the use of water harvesting catchments with various establishment techniques, apron slope lengths, and apron gradients.

\section{Study Area}

\section{Location}

The study was conducted at the Arid Zone Research Substation adjacent to Dera Ismail Khan, which is a city in an arid zone in the extreme south and southwestern side of the North West Frontier Province (NWFP) of Pakistan. The substation lies near $32^{\circ} 40^{\prime} \mathrm{N}$ latitude and $71^{\circ} 20^{\prime} \mathrm{E}$ longitude. The Dera Ismail Khan area is bounded on the north by the lower edge of the Marwat piedmont, and on the west by the foot of the Sulaiman Range, on the east by the Indus River flood plains and on the south by a similar arid area of Dera Ghazi Khan (D.G. Khan). Although rainfall is limiting, $68 \%$ of the area still depends largely on rainfall for rainfed (barani) agriculture and forage production for livestock. 


\section{Climate}

The climate of the study area is arid subtropical continental. Because of low humidity, continental location, and scarce vegetation, there are great seasonal and daily variations in temperature, The mean maximum temperature in June is $42^{\circ} \mathrm{C}$, while the maximum temperature in the area can reach $45^{\circ} \mathrm{C}$. The mean minimum January temperature is $4.4^{\circ} \mathrm{C}$.

Precipitation is one of the most critical determinants of the type of barani agriculture practiced. Crop and forage yields are significantly and positively related to seasonal and total precipitation. The mean annual precipitation varies from about $180 \mathrm{~mm}$ in the south to about $305 \mathrm{~mm}$ in the north. Fifty percent of the annual precipitation occurs in summer (July-August) with the advent of the monsoon season. The summer monsoon rains come as frequent thunderstorms and the heavy downpours result in considerable surface runoff. The winter rains (December-March) tend to occur in gentle showers of long duration.

Evapotranspiration is high in the summer due to high temperatures and low relative humidity. The peak rate is reached in the hottest months, June and July, when evaporation can be as high is $300 \mathrm{~mm}$ per month. The annual evapotranspiration rate for the area is $2,000 \mathrm{~mm}$. Such high rates increase water requirements of Kharif (summer) agriculture and forage crops and can also reduce seed germination and cstablishment rates due to rapid drying of the soil and consequent soil crusting.

\section{Soils.}

Soils are derived from sloping piedmonts and consist predominantly of clayey and silty outwashes derived from the Sulaiman Range. Soils are moderately to strongly calcareous and belong to the Entisol and Aridisol soil orders. The soil in the study area is silty and strongly calcareous with a pH value of 7.2 and low organic matter content.

\section{Land Capability}

Dera Ismail Khan includes lands in the classes: (i) "land suitable for irrigation" (18\%), (ii) "marginal torrent-watered land (20\%), (iii) "agriculturally unproductive land" and "unproductive arable land" (31\%), (iv) "poor grazing potential land" (10\%), and other classes (21\%). Based on climate, the woody vegetation of the area is classified as dry tropical thorn forests. Characteristic woody species include: jandi (Prosopis spicigera L.), karir (Capparis decidua Edgew.), jal or pilu (Salvadora oleoides Decne.), kikar (Acacia nilotica Del.), ber (Ziziphus jujuba Mill.), mesquite (Prosopis juliflora Benth.), frash (Tamarix articulata Vahl), and ak (Calotropis procera W. Aiton). Common grass species include sar-kand (Saccharum munja Roxv.), dib (Eragrostis cynosuroides (Retz.) Beauv.), chimber (Eleusine flagellifera Nees), and khabbal (Cynodon dactylon (L.) Pers.). But most of the area is devoid of natural vegetation either due to clear cutting for cultivation or fuelwood purposes.

\section{Methods}

\section{Experimental Design}

The soil at the study site was tilled with a tractor and tiller in leveled plots (cultivated areas). Plot size (CA) was $8 \mathrm{~m} \times 30 \mathrm{~m}$. Except for plots in the control treatment, each plot had adjacent sloping aprons (C). The length of the aprons were $4 \mathrm{~m}$ and $5 \mathrm{~m}$ (each $30 \mathrm{~m}$ wide) and were differentially graded at $7 \%, 10 \%$, and
15\% slope. Hence, the catchment:cultivated area ratio (C:CA) of treatments having $4 \mathrm{~m}$ and $5 \mathrm{~m}$ slope lengths were $1: 1$ and 1.25:1, respectively. The 7 catchment treatments were replicated in 3 blocks (Fig. 1) in a factorial arrangement.

Apron Lengths and Slopes

\begin{tabular}{|c|}
\hline $5 \mathrm{~m}, 10 \%$ \\
\hline $5 \mathrm{~m}, 15 \%$ \\
\hline $5 \mathrm{~m}, 7 \%$ \\
\hline $4 \mathrm{~m}, 15 \%$ \\
\hline $4 \mathrm{~m}, 10 \%$ \\
\hline $4 \mathrm{~m}, 7 \%$ \\
\hline $0 \mathrm{~m}, \quad 0 \%$ \\
\hline
\end{tabular}

Replication 1

\begin{tabular}{|c|}
\hline $5 \mathrm{~m}, 10 \%$ \\
\hline $5 \mathrm{~m}, 7 \%$ \\
\hline $5 \mathrm{~m}, 15 \%$ \\
\hline $4 \mathrm{~m}, 7 \%$ \\
\hline $4 \mathrm{~m}, 15 \%$ \\
\hline $4 \mathrm{~m}, 10 \%$ \\
\hline $0 \mathrm{~m}, 0 \%$ \\
\hline
\end{tabular}

Replication 2

\begin{tabular}{|c|}
\hline $4 \mathrm{~m}, 15 \%$ \\
\hline $4 \mathrm{~m}, 10 \%$ \\
\hline $4 \mathrm{~m}, 7 \%$ \\
\hline $5 \mathrm{~m}, 10 \%$ \\
\hline $5 \mathrm{~m}, 7 \%$ \\
\hline $5 \mathrm{~m}, 15 \%$ \\
\hline $0 \mathrm{~m}, 0 \%$ \\
\hline
\end{tabular}

Replication 3

Fig. 1. Schematic diagram of plot locations in blocks.

Runoff water produced from the slopes of aprons was collected in the cultivated areas. The cultivated areas of each catchment was further divided into 7 subplots $(8 \mathrm{~m} \times 4 \mathrm{~m}$ ) with $1 \mathrm{~m}$ borders on each end (Fig. 2). The subplots were randomly assigned 7 vegetation treatments, which included seed sowing the tuft planting of buffel grass, seed sowing and tuft planting of gorkha grass, mixed seed sowing of buffel and gorkha grass, tuft planting of blue panicum and tuft planting of khev grass. A tuft is a grass plant with a root system at least $15-20 \mathrm{~cm}$ deep and stubble 6-10 $\mathrm{cm}$ above ground. Khev grass is native to the area and its tufts were collected from remmant plants under the mesquite in the Rakh Miran Range of Dera Ismail Khan. Seed of khev grass 


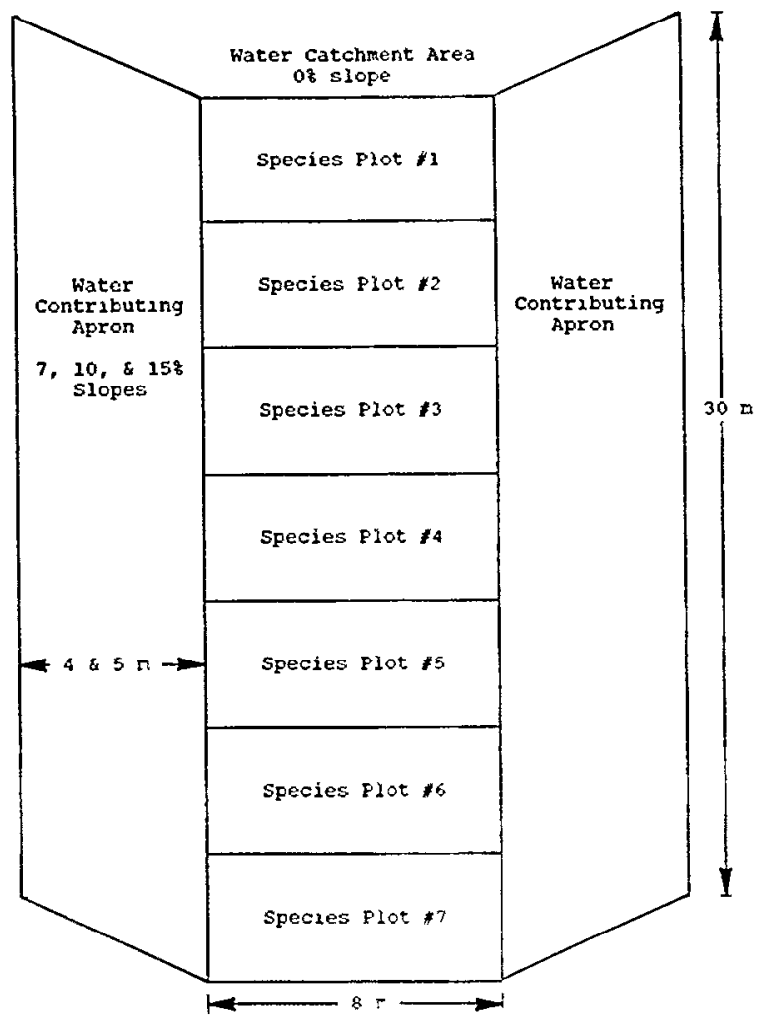

Fig. 2. Diagram of a water catchment area with water contributing aprons.

could not be procured for sowing because the area was severely grazed and seed heads were missing. Buffel grass, gorkha, and blue panicum are native species of adjacent desert rangelands. Their seed and tufts were collected from the Rakh Dagar Kotli Experimental Range Station, District Bakhar. Planting was conducted in July 1990 . The seed rate used for both species separately and in mixtures was $5 \mathrm{~kg} \mathrm{ha}^{-1}$. Tufts of buffel grass, gorkha grass, and blue panicum were planted at a spacing of $50 \mathrm{~cm} \times 30$ $\mathrm{cm}$. Tufts of khev grass were spaced $30 \mathrm{~cm}$ apart.

The phytomass $\left(\mathrm{kg} \mathrm{ha}^{-1}\right)$ was estimated for the seeded and tuft planted grass species at the end of each growing season by clipping plants to ground level using $1 \mathrm{~m}^{z}$ quadrats. The quadrat in each subplot was randomly located and then harvested with a sickle. The phytomass material for each quadrat was placed separately in paper bags, air dried, weighed in grams, and converted to kilograms per hectare. Foliar cover within each subplot was visually estimated using a $1 \mathrm{~m}^{2}$ quadrat divided into 4 equal square subquadrats.

\section{Statistical Analysis}

To estimate treatment effects on phytomass and cover, 2 separate statistical analyses were conducted using all plots and only successfully established plots. The experimental design was a split plot with a randomized complete block design on the whole plot with a block equal to location, and treatment configuration equal to vegetation treatment and year and month within year as a split factor. Single degree of freedom contrasts were done to compare the specified treatment means. The Chi-square test for homogeneity was performed to evaluate whether or not slope and vegetation species treatments had the same establishment rate in 2 growing seasons.

Overall differences among treatments were tested using an analysis of variance test by the General Linear Model (GLM) procedure (SAS Institute 1985). Tests were evaluated at the 0.05 significance level of probability. If the analysis of variance F-test was significant at the chosen alpha level, Scheffe's test was used for all possible comparisons among treatment means for significant treatment $\mathrm{f}$-values.

\section{Results}

\section{Meteorological Data}

Mean maximum monthly temperatures over the duration of the study ranged from 21 to $42^{\circ} \mathrm{C}$, and mean minimum monthly temperatures ranged from 4 to $29^{\circ} \mathrm{C}$ (Table 1). January was the coolest month and June was the hottest. Maximum pan evaporation occurred during June and minimum in December. Periods of high precipitation occurred in late summer and late winter-early spring. These temperature, evaporation, and precipitation patterns are similar to the long-term averages for the area.

Table 1. Mean monthly meteorological data between June 1990 and May 1991 at the Arid Zone Research Sub-Station, Dera Ismail Khan.

\begin{tabular}{|c|c|c|c|c|c|c|}
\hline \multirow{2}{*}{\multicolumn{2}{|c|}{$\begin{array}{l}\text { Month and } \\
\text { Year }\end{array}$}} & \multicolumn{2}{|c|}{ Temperature } & \multirow{2}{*}{ Pan } & \multirow{2}{*}{\multicolumn{2}{|c|}{$\begin{array}{c}\text { Rainfall } \\
\text { 1990-1991 Longterm }\end{array}$}} \\
\hline & & Maximum & Minimum & & & \\
\hline & & ${ }^{\circ} \mathrm{C}$ & ${ }^{\circ} \mathrm{C}$ & $(\mathrm{mm})$ & & $(\mathrm{mm})$ \\
\hline Jun & 1990 & 42 & 28 & 330 & 10.0 & 10.0 \\
\hline Jul & 1990 & 39 & 29 & 310 & 46.0 & 35.0 \\
\hline Aug & 1990 & 37 & 27 & 248 & 25.3 & 31.0 \\
\hline Sep & 1990 & 35 & 25 & 210 & 32.1 & 3.0 \\
\hline Oct & 1990 & 32 & 17 & 155 & 20.0 & 6.5 \\
\hline Nov & 1990 & 28 & 14 & 90 & 0.0 & 7.4 \\
\hline Dec & 1990 & 22 & 5 & 48 & 22.5 & 7.8 \\
\hline Jan & 1991 & 21 & 4 & 62 & 0.0 & 2.1 \\
\hline Feb & 1991 & 21 & 8 & 63 & 10.0 & 20.9 \\
\hline Mar & 1991 & 26 & 12 & 102 & 46.0 & 43.8 \\
\hline Apr & 1991 & 30 & 17 & 144 & 50.0 & 31.6 \\
\hline May & 1991 & 32 & 21 & 279 & 12.0 & 20.4 \\
\hline
\end{tabular}

\section{Forage Production}

With all treatments combined, the first half of 1991 had more production $\left(2,059 \mathrm{~kg} \mathrm{ha}^{-1}\right)$ than in the last half of $1990\left(901 \mathrm{~kg} \mathrm{ha}^{-1}\right)$. Total precipitation for the 2 periods was similar (Table 1 ). Differences in production are attributed to plants in 1991 being better established since the plots were planted in July of 1990 . A conservative rule of thumb commonly followed is that seeded stands on range will not be mature enough for grazing until after the second full growing season following seeding (Reynolds and Martin 1968, Vallentine et al. 1963).

In general, plots with aprons had significantly higher mean forage yiclds $\left(1,684 \mathrm{~kg} \mathrm{ha}^{-1}\right)$ than the control treatment $\left(256 \mathrm{~kg} \mathrm{ha}^{-1}\right)$. Plots with $5 \mathrm{~m}$ aprons (C:CA 1.25:1) produced significantly more forage than plots with $4 \mathrm{~m}$ aprons (C:CA 1:1) $(2,057$ and 1,311 $\mathrm{kg} \mathrm{ha}^{-1}$, respectively). Similar results were found by Schreiber and Frasier (1978) with blue panicum (Panicum antidotale Retz.). In their study, production was $250 \mathrm{~kg} \mathrm{ha}^{-1}$ in a control area receiving 
less than $250 \mathrm{~mm}$ of precipitation while catchments with C:CA ratios of $2: 1$ produced $900 \mathrm{~kg} \mathrm{ha}^{-1}$.

Plots with 7,10 , and $15 \%$ apron gradients had similar forage production $\left(1,798,1,697\right.$, and $\left.1,557 \mathrm{~kg} \mathrm{ha}^{-1}\right)$, respectively. Therefore, no advantage was gained by raising the slopes to 10 or $15 \%$.

Overall, tuft plantings produced significantly more forage than seeding (1,780 and $1,338 \mathrm{~kg} \mathrm{ha}^{-1}$, respectively). Khev tuft production was not included in these calculations because no plots were seeded with Khev. Although tuft plantings produced more forage than seeding, tuft collection and planting is more laborious than seed collection and planting. Vallentine (1989) uses the term artificial revegetation to be synonymous with seeding. However, he admits that vegetative plantings do offer alternative revegetation methods for special situations. He gives the example where planting sprigs (rhizome sections) is used for establishing bermudagrass (Cynadon dactylon (L.) Pers.) (Rechenthin et al. 1965).

The forage yield was highest from $5 \mathrm{~m}$ aprons (7\% gradient), followed by that from $5 \mathrm{~m}$ aprons with $15 \%$ gradient, then $5 \mathrm{~m}$ aprons with $10 \%$ gradient (Table 2). However, these differences were not significant. Also, there were no significant differences among the treatments with $4 \mathrm{~m}$ aprons.

There were no significant differences between production of ghorka, panicum, and buffel grass from tufts, but all 3 produced more than Khev grass. The tufts of ghorka and buffel grass pro-

Table 2. Mean forage production $\left(\mathrm{kg} \mathrm{ha}^{-1}\right)$ and cover (\%) for various apron lengths and gradients.

\begin{tabular}{lccc}
\hline \hline $\begin{array}{l}\text { Apron } \\
\text { length }\end{array}$ & Gradient & $\begin{array}{c}\text { Forage } \\
\text { production }\end{array}$ & $\begin{array}{c}\text { Forage } \\
\text { cover }^{3}\end{array}$ \\
\hline$(\mathrm{m})$ & $(\%)$ & $\begin{array}{c}\left(\mathrm{kg} \mathrm{ha}^{-1}\right) \\
256 \mathrm{~b}\end{array}$ & $(\%)$ \\
0 & 0 & $1,246 \mathrm{ab}$ & $9.2 \mathrm{~b}$ \\
4 & 7 & $1,489 \mathrm{ab}$ & $34.6 \mathrm{ab}$ \\
4 & 10 & $1,198 \mathrm{ab}$ & $40.0 \mathrm{ab}$ \\
4 & 15 & $2,349 \mathrm{a}$ & $32.7 \mathrm{ab}$ \\
5 & 7 & $1,906 \mathrm{a}$ & $62.2 \mathrm{a}$ \\
5 & 10 & $1,915 \mathrm{a}$ & $50.1 \mathrm{a}$ \\
5 & 15 & $51.1 \mathrm{a}$ \\
\hline
\end{tabular}

${ }_{1}^{1}$ Treatment means within a column with the same letter are not significantly different $(P$ 30.05 ) by Scheffe grouping.

Analysis of variance $\mathrm{F}(6,12)=8.46, \mathrm{p}=0.0001$ for the treatments. $\mathrm{MS}=$ $228,308,879.8$.

Analysis of variance $\mathrm{F}(6,12)=9.98, \mathrm{p}=0.0001$ for the treatments. $\mathrm{MS}=1,225.6$.

duced almost $30 \%$ more forage yield than the seed sowing (Table 3). The contrast comparing mixed seed sowing of buffel + ghorka grass and their monocultures showed no significant differences.

The analysis for production showed a significant $(p<0.05)$ species $\times$ planting method $\times$ slope $\times$ gradient $\times$ season interaction (Figs. 3 and 4). The most production came from ghorka tufts in the 5-m long slopes with 7\% gradient in 1991. This was followed closely by production from buffel seed, buffel tufts, ghorka seed, mixed seed (ghorka + buffel), and panicum tufts. Because of greater labor requirements for planting tufts, the best treatments are probably seeding these species on $5 \mathrm{~m}$ long slopes with a 7\% gradient.

\section{Forage Cover}

In general, the slope treatment responses for foliar cover (Tables 2 and 3 Figs. 5 and 6) were similar to the responses for forage production (Table 2 and 3 and Figs. 3 and 4).

With all treatments combined, the first half of 1991 had significantly more cover $(52.1 \%)$ than in the last half of 1990 (27.9\%).

\section{Forage Production \\ Last Half of 1990}

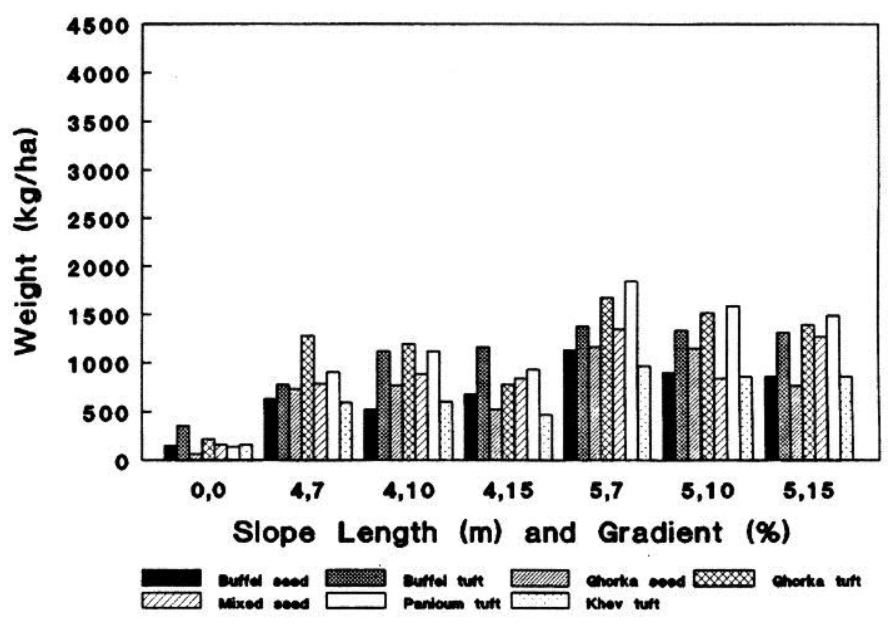

Fig. 3. Forage production $(\mathrm{Kg} / \mathrm{ha})$ at the end of 1990 following planting in mid-1990.

Similar to differences in production, higher cover in 1991 is attributed to plants in 1991 being the oldest and most productive since the plots were planted just prior to the last half of 1990 .

In general, with pooled data, plots with aprons had significantly higher cover $(45.1 \%)$ than the control treatment $(9.2 \%)$. With pooled data, plots with $5 \mathrm{~m}$ aprons (C:CA 1.25:1) produced significantly more cover plots with $4 \mathrm{~m}$ aprons (C:CA 1:1) (54.4 and $35.8 \%$, respectively).

Plots with 7,10 , and $15 \%$ apron gradients had similar cover (48.4, 45.1, and $41.9 \%$, respectively). Therefore, as was the case for forage production, energy is not needed to raise the slopes to 10 or $15 \%$.

Overall, tuft plantings produced a similar cover to seeding (42.3 and $35.8 \%$, respectively). Khev tuft cover was not included in these calculations because no plots were Khev seeded. Cover was similar from all aprons regardless of gradient (Table 2).

There were no significant differences among cover of ghorka, panicum, buffel grass, and khev grass. The tufts of ghorka and buffel grass produced $36 \%$ more cover than the seed sowing (Table 3). The contrast comparing mixed seed sowing of buffel + ghorka grass and their monocultures showed no significant difference.

Table 3. Mean forage production $\left(\mathrm{kg} \mathrm{ha}^{-1}\right)$ for various species ${ }^{1}$.

\begin{tabular}{|c|c|c|c|}
\hline Species & $\begin{array}{l}\text { Reproductive } \\
\text { form }\end{array}$ & $\begin{array}{c}\text { Forage } \\
\text { production }^{2}\end{array}$ & $\begin{array}{l}\text { Forage } \\
\text { cover }^{3}\end{array}$ \\
\hline Ghorka & tuft & $\begin{array}{l}\left(\mathrm{kg} \mathrm{ha}^{-1}\right) \\
1,838 \mathrm{a}\end{array}$ & $\begin{array}{r}(\%) \\
44.5 \mathrm{ab}\end{array}$ \\
\hline Panicum & tuft & $1,781 \mathrm{a}$ & $36.3 \mathrm{abc}$ \\
\hline Buffel & tuft & $1,721 a b$ & $46.0 \mathrm{a}$ \\
\hline Khev & tuft & $1,007 \mathrm{~d}$ & $46.0 \mathrm{a}$ \\
\hline Ghorka & seed & $1,319 \mathrm{bcd}$ & $32.6 \mathrm{c}$ \\
\hline Buffel & seed & $1,235 \mathrm{~cd}$ & $34.2 \mathrm{bc}$ \\
\hline Mixed & seed & $1,461 \mathrm{abc}$ & $40.7 \mathrm{abc}$ \\
\hline
\end{tabular}

(Ghorka +

Buffel)

${ }^{1}$ Treatment means within a column with the same letter are not significantly different $(P>0.05)$ by Scheffe grouping.

${ }_{3}$ Analysis fo variance $\mathrm{F}(6,84)=13.16, \mathrm{pl}=0.0001$ for the treatments. $\mathrm{MS}=31,241,811.7$.

${ }^{3}$ Analysis of variance $\mathrm{F}(6,84)=6.62, \mathrm{p}=0.0001$ for the treatments. $\mathrm{MS}=200.7$. 


\section{Forage Production \\ First Half of 1991}

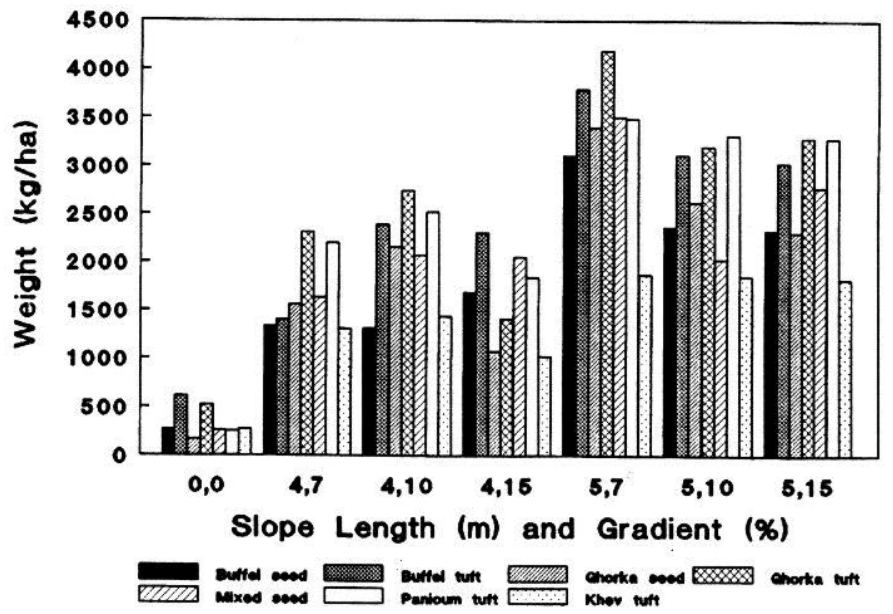

Fig. 4. Forage production $(\mathrm{Kg} / \mathrm{ha})$ at in mid-1991 following planting in mid-1990.

The analysis for cover also showed a significant $(p<0.05)$ species $\times$ planting method $\times$ slope $s$ gradient $\times$ season interaction (Figs. 5 and 6). The most cover came from buffel tufts in the $5 \mathrm{~m}$ long slopes with $7 \%$ gradient in 1991 . This was followed closely by production from buffel seed, ghorka seed, ghorka tufts, mixed seed (ghorka + buffel), and panicum tufts. As mentioned for forage production, because of greater labor requirements of planting tufts, the best treatments are probably seeding these species on 5 $\mathrm{m}$ long slopes with a $7 \%$ gradient.

These production and cover values are very high considering the area only receives $215 \mathrm{~mm}$ of precipitation each year and evaporation rates are so high. Range seeding is generally recommended where the average annual precipitation is $280 \mathrm{~mm}$ or more, with some success expected in the 230 to $250 \mathrm{~mm}$ zones

\section{Forage Cover Last Half of 1990}

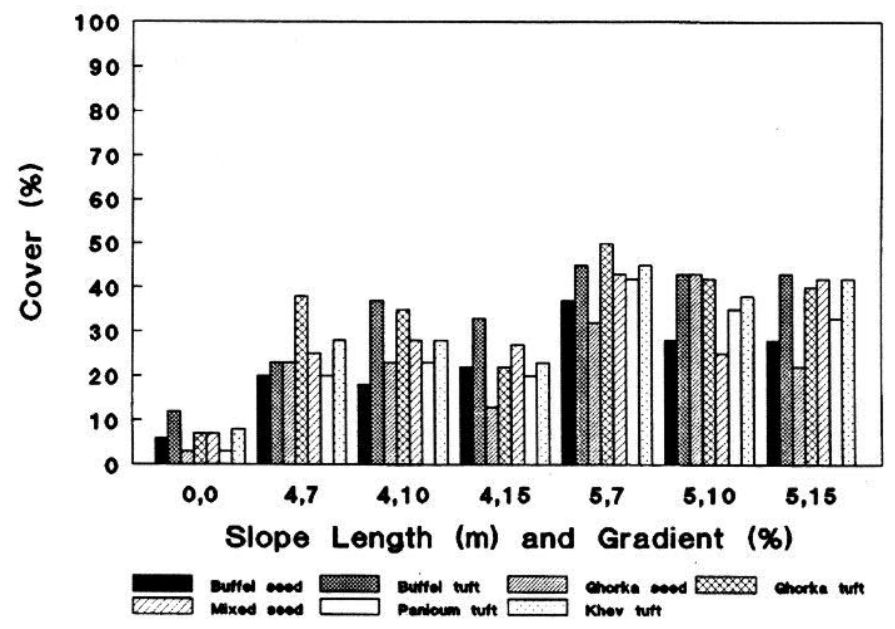

Fig. 5. Forage cover $(\%)$ at the end of 1990 following planting in mid-1990.
Forage Cover

First Half of 1991

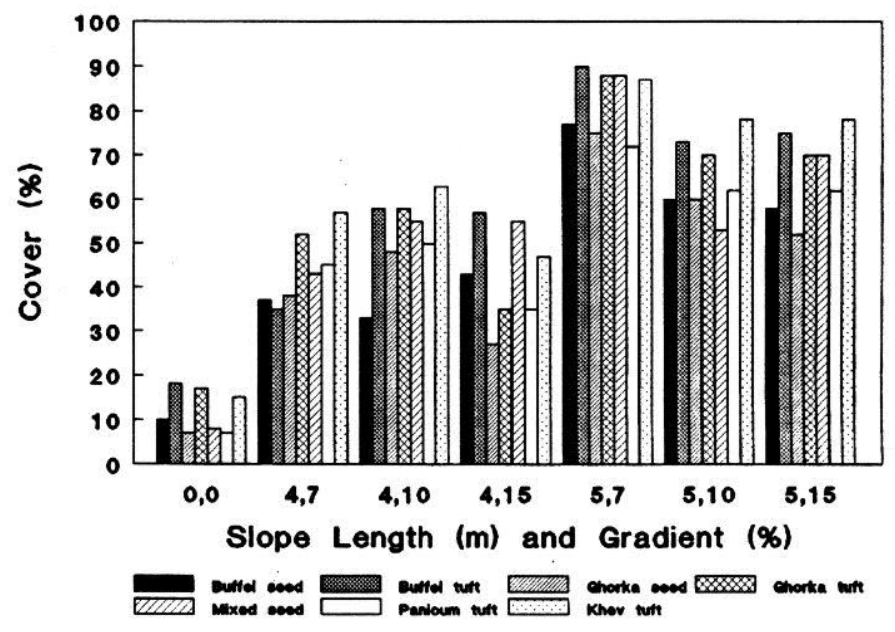

Fig. 6. Forage cover $(\%)$ at in mid-1991 following planting in mid1990.

(Cook 1966, Martin 1966, Plummer et al. 1955, Reynolds and Martin 1968, Shown et al. 1969). Using catchment aprons allows revegetation in areas normally considered marginal or too dry for dependable plant establishment.

\section{Literature Cited}

Cook, C.W. 1966. Development and use of foothill ranges in Utah. Utah Agr. Exp. Sta. Bul. 461., Utah State Univ., Logan, Ut.

Evenari, M., L. Shanan, and N.H. Tadmor. 1968. Runoff farming in deserts: Part 1; Experimental layout. Agron J. 60:29-38.

Harden, A. 1975. Discussion session 1. In: G.W. Frasier (ed.). Proceedings Water Harvesting Symposium, USDA Res. Serv., ARS W-22, Washington, D.C.

Martin, S.C, 1966. The Santa Rita Experimental Range. USDA Forest Serv. Res. Paper RM-22., Ft. Collins, Colo.

Myer, L.E. 1975. Water harvesting-2000 B.C.-1974 A.D. In: G.W. Frasier (ed.). Proceedings Water Harvesting Symposium, USDA, Agr. Res. Serv., ARS W-22, Washington, D.C.

Plummer, A.P., A.C. Hull, Jr., G. Stewart, and J.H. Roberston. 1955. Seeding rangelands in Utah, Nevada, southern Idaho, and western Wyoming. USDA Agr. Handb. 73, Washington, D.C.

Population Census. 1981. Demographic and socio-economic indicators, North West Frontier Province. Pakistan Gov., Islamabad.

Rechenthin, C.A., H.M. Bell, R.J. Pederson, D.B. Polk, and J.E. Smith, Jr. 1965. Grassland restoration. Part III. Re-establishing forage plants. USDA, Soil Conserv. Serv., Temple, Tex.

Reynolds, H.G. and S.C. Martin. 1968. Managing grass-shrub cattle ranges in the southwest, rev. USDA Agr. Handb. 162, Washington, D.C.

SAS Institute Inc. 1985. SAS User's Guide: Statistic Version 5th Edition. Cary, N.C.

Schreiber, H.A. and G.W. Frasier. 1978. Increasing rangeland forage production by water harvesting. J. Range Manage. 31:37-40.

Shown, L.M., R.F. Miller, and F.A. Branson. 1969. Sagebrush conversion to grassland as affected by precipitation, soil, and cultural practice. J. Range Manage. 22:303-311.

Vallentine, J.F., C.W. Cook, and L.A. Stoddart. 1963. Range seeding in Utah. Utah Agr. Ext. Serv. Cir. 307:20, Utah State Univ., Logan, Ut.

Vallentine, J.F. 1989. Range development and improvements. third edition, Academic Press, Inc. San Diego, Calif. 